\section{New vaccine and initiative mean end of rabies in sight for Europe?}

\section{London}

EUROPE's largest field trial so far of a genetically modified organism has been launched. At the end of October, a 435square-kilometre tract of land in southern Belgium was baited with a recombinant DNA vaccine against fox rabies. Within two years, it should be clear whether the vaccine is better able to immunize foxes against rabies than the traditional attenuated viral vaccine, but before then the European Commission hopes to have launched a Community-wide drive to vaccinate all foxes in areas where there is rabies and thus to eradicate the disease from Europe.

The Belgian trial will test a vaccinia virus modified to contain a rabies virus gene produced by the French companies Transgène and Rhône-Mérieux. Unlike

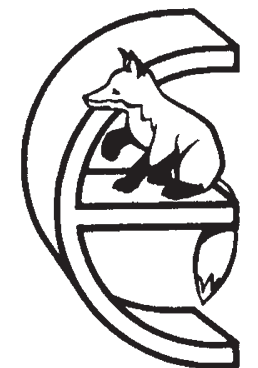

Symbol of the European Commission's community-wide drive to control rabies in foxes.

attenuated viruses, the recombinant vaccinia virus can immunize all relevant mammalian species and is not toxic to any of them, according to Professor Paul Pierre Pastoret of the University of Liège, who is in charge of the trial. But because the vaccine is a genetically modified organism, testing it in the field has required extensive approval, ultimately from the National Council of Health, an advisory body to the Belgian Ministry of Health.

The test area has been chosen because it has the lowest density of inhabitants in the country combined with a high incidence of rabies: in the past five years, 148 rabid animals, mainly foxes and cows, have been recorded. Forestry rangers have now distributed 15 baits containing the recombinant DNA vaccine in every square kilometre of the test area apart from a small area that will be studied more intensively by Pastoret and his colleagues.

The success of the test will be measured chiefly by the extent to which foxes in the area become immunized against rabies virus as a result of eating the bait. This will require shooting a number of foxes and trapping others. Additional tests will monitor the uptake of bait and any signs of vaccinia virus lesions. Other domestic and wild mammals will also be monitored.

While the new vaccine is under test in one locality in southern Belgium, the remainder of the area has recently been baited with attenuated rabies virus. The plan is to eradicate rabies from the whole of the country, as the Swiss have done.

More ambitiously, the European Commission has proposed a plan of action that would remove the disease from the whole Community. If approval is forth-
Munich

Tin: European Community (EC) is preparing a positive response to the international enthusiasm for mapping and sequencing the human genome, but is having to contend with objections of an ethical character from West Germany.

The community may begin with a programme called "Predictive Medicine" costing a modest 15 million ECU ( 1 ECU $=\$ 1.2(0)$ as early as next spring. The first objective is to construct a high-resolution gene map. Independently, the Paris institute CEPH (Centre d'Etude du Polymorphisme Humain) has already begun identifying polymorphisms in the DNA of 40 families. The EC would like the number of families to be increased to 60 and would also like to set up a European network for the cloning and analysis of DNA, together with a parallel computing network to analyse the data.

The second goal is to construct libraries of DNA clones and to store and distribute clones free of charge to European laboratories interested in matching genetic material to the cloned fragments. Finally. the EC would like to improve " advanced genetic technologies" and spread both the technology and the practical knowledge more evenly through the community.

West German parliamentarians do not object to the substance of the programmes, but rather to their intentions, which they claim are based on eugenic principles similar to those of the $\mathrm{Nazi}$ movement. Angry words exchanged between Bonn and Brussels bode ill for future agreement. Community officials have been accused of advocating a new form of "racial hygiene" while West Germans have been scolded for "whipping up a misunderstanding". The programme itself has been criticized from other quarters as meagre compared to those being discussed in Japan and already underway in the United States. But an EC official said that the amount committed "does not mean we think that 15 million ECU is all this is worth". coming, Community-wide vaccination could be under way next year. To prevent the spread of rabies back into the Community from the east, it would be necessary either to persuade countries on the eastern border also to vaccinate or to maintain a permanently vaccinated zone 60 kilometres wide along the border.

A particular spur for action is that all barriers to trade within the Community are supposed to be dismantled by 1992; one such barrier is the six-month quarantine presently imposed by the United Kingdom and Ireland.

Peter Newmark
The medical justification given in the proposal has generated most of the controversy. Genetic diseases are said to be "distressing" and "socially very expensive", so that the possibility of relieving or preventing them is promising. The proposal has also given offence by declaring that the programme will strengthen European industry in a "potential European market for DNA probes ... of $1,000-$ 2,000 ECU a year"

But, the proposal goes on, the use of genetic information "does raise ethical questions". A study group has been created with a West German, Ernst-Ludwig Winnaker, as its chairman to investigate the broader implications.

In a joint statement on 8 November approved by all the major parties, the Research and Technology Committee of the Bundestag demanded changes in the EC proposal. The committee's strongest objection concerned the way knowledge gained from screening for inheritable diseases could be implemeneted. Without modifying the human germ line, the critics contend, transmission can only be "prevented" by persuading or even forcing people not to reproduce; a version of "eugenic justification" the committee felt was inappropriate.

This issue will be debated in the plenum of the Bundestag later this month. But the most the parliament could do would be to call upon the West German government to oppose the programme in Brussels.

Ironically, West German research organizations are proceeding apace in setting up a coordinating body for West German research into the human genome. The research council Deutsche Forschungsgemeinschaft (DFG) already has a Priority Programme in "human genome analysis with molecular biological methods", though no West German group has attained international recognition in genome analysis and mapping. The DFG and the Research and Technology Ministry are trying to decide what to do next and how much to invest. 